\title{
Proposal for Palaeomagnetic Research of Endogenous Processes in Eastern and South-Eastern Africa -in the Broader Adjacent Region of the Rift Valley of Eastern Africa
}

\author{
Václav HANUŠ and Miroslav KRS \\ Geological Institute, Czechoslovak Academy of Science, Praha
}

(Received January 12, 1970)

In the report “International Upper Mantle Project-Programs and International Recommendations, 1960-1963", compiled and issued by the Secretariat of the Upper Mantle Committee in Los Angeles in January 1964, Dr. B.H. Baker of the Geological Survey of Kenya proposed to launch a survey of the Kenya Rift Valley as a part of broad research on the upper Earth mantle. Professor V.V. Belousov, chairman of the Bureau of Upper Mantle Committee prepared suggestions for an extensive survey of the Eastern African Rift System, based on a rational complex of geological and geophysical methods (pp. 4447). This grand project is hereby suggested to be supplemented by a palaeomagnetic research of volcanic complexes and products of hydrothermal mineralizations.

The complex of problems dealing with palaeomagnetic dating of hydrothermal deposits in the Carpathian and Bohemian Massif areas (Czechoslovakia and Germany) was recently studied here. Investigation of remanent magnetization of hydrothermal and pneumatolytic parageneses from 40 deposits revealed that palaeomagnetism can be made use of for chronological dating and correlating epigenetic deposits both in tectonically consolidated and mobile areas. The palaeomagnetic technique applied in Central Europe was found useful for dating Palaeozoic and younger deposits (V. Hanuš and M. Krs 1963 a,b,c; M. Krs 1964).

It is believed that in the Rift System of Eastern Africa the palaeomagnetic technique could substantially contribute to the elucidation of some fundamental geological and geophysical problems suggested for investigation in the project. Application of the palaeomagnetic method to studying volcanic rocks and products of hydrothermal mineralization will yield data on the possibility of chronological correlation of magmatites with certain products of hydrothermal mineralization as well as on the age of tectonic rifts, filled at present with products of hydrothermal processes. These data can supply objective criteria for time classification of fault systems in the region of eastern African crystalline complexes.

The determination of age of the main deposit types in Tanganyika and Kenya (as are proposed for the initial part of research) will yield important data for the reconstruction of the development and variability of magmatic complexes of this region which will be 
chronologically congruent with the hydrothermal mineralization of a certain chemism. Dating of deposits by the palaeomagnetic method is especially suitable in old crystalline complexes in which a chronological determination of epigenetic mineralization is generally impossible by direct geological methods. It is probable that many ore accumulations in eastern Africa which, for lack of reliable data, are considered to be of equal age as deep magmatic rocks in their vicinity, will not display any direct genetic or chronological relationships to subsurface magmatic (especially granitoid) rocks. Their chronological and genetic relationship to dislocation zones of subsurface extent is rather likely but difficult to establish by methods, generally applied at present.

Recently, a certain independence of hydrothermal mineralization on magmatic complexes has been repeatedly indicated, but their spatial association with deep-seated tectonic zones of long-term evolution. Palaeomagnetism will permit to differentiate between hydrothermal parageneses of different age and hence to estimate the life history of the eastern African rift zone. In Czechoslovakia, it was possible to distinguish hydrothermal deposits of two different ages in a metallogenic region previously considered as uniform and thus to establish the existence of deep tectonic zones bringing about mineralization at different geological periods.

The eastern African region is in our opinion particularly suited for applying the palaeomagnetic dating technique to products of hydrothermal mineralizations which are older than Palaeozoic. Such conditions cannot be found anywhere in Europe. A significant favourable circumstance in this respect lies in the numerous results of radioactive geochronology (especially the results of A. Holmes) obtained from an investigation of eastern African rock complexes. Some palaeomgnetic results could be confronted with the results of radioactive dating which will be possible in the Geochronological Laboratory of the Czechoslovak Academy of Sciences in Prague (e.g. during research of mica-bearing pegmatites with mineral paragenesis and remanent magnetism).

On the basis of general data available to us on the hydrothermal mineralization of Kenya and Tanganyika it is assumed that for the purposes of palaeomagnetic dating it will be most convenient to use mineral parageneses from deposits of $\mathrm{Au}, \mathrm{Pb}-\mathrm{Zn}, \mathrm{Cu}$ and $S n-W$. In Kenya the most suitable terrain would be in the southwestern part of the country, comprising pre-Cambrian rocks of the Bukoban and Kavirondian Systems with pegmatites and deposits of $\mathrm{Au}, \mathrm{Ag}, \mathrm{Mo}, \mathrm{CaF}$, rare-earth minerals and the like, and the Nyanzian System with mineralizations of $A u, A g, P b-Z n, C o, M o$ and $C a F_{2}$. In Tanganyika the most suitable region for the palaeomagnetic research will be in the vicinity of Lake Victoria (Karagwe Goldfield, Mwanza Goldfield and Musoma Goldfield) and the area in the vicinity of Iramba Sekenke and Mpanda Mineral Field. In southern Tanganyika the region around Lupa Geldfield seems to be most suitable.

More details on the economically insignificant products of hydrothermal mineralization as will be gathered at the sites from local experts will undoubtedly establish the existence of sufficient further parageneses with remanent magnetism. Hydrothermal fillings of mineralogical character will also be applicable for dating the fault systems of 
Proposal for Palaeomagnetic Research of Endogenous Processes in Eastern and South-Eastern 167 Africa-in the Broader Adjacent Region of the Rift Valley of Eastern Africa

different directions and different distribution in the crystalline complexes.

One of the main prerequisites for successful application of the palaeomagnetic dating technique (especially in old pre-Palaeozoic complexes) is the certainty of absence of rotational movements of tectonic blocks in the region of the old consolidated shield and this is very well fulfilled in the castern African region.

Understanding of the history of endogenous processes in the broader area of the Rift System of eastern Africa will undoubtedly contribute to forming a more complete picture of the entire zone which is generally considered as an ideal research object in connection with the Upper Mantle Project. It is therefore suggested:

(1) To study the palaeomagnetism of hydrothermal and pneumatolytic deposits and of some magmatites with a view to their dating and mutual correlation.

(2) To extend palaeomagnetic research to rocks dated biostratigraphically with the objective of completing the pole-wandering curve on the African continent. It is assumed that gathering of samples from the deposits and adjacent rocks (including sedimentary ones) would proceed simultaneously. This work would supplement the fundamental palaeomagnetic knowledge of Africa and of palaeogeographic reconstructions(Gondwana).

(3) To study the magnetism and palaeomagnetism of magmatites and volcanics in order to compile data necessary for interpreting the prospective magnetic measurements, whether carried out on surface and from the air.

\section{References}

V. Hanuš, M. Krs 1963 a : Über die Anwendung des Paläomagnetismus zur Altersbestimmung Hydro. thermaler Erzlagerstätten. Neues Jahrbuch für Mineralogie. Abhandlungen, 100, 1, 87-100. Stuttgart.

V. Hanuš, M. Krs 1963 b: Palaeomagnetic Dating of Hydrothermal Deposits in Gzechoslovakia. Geophysical Journal of the Royal Astronomical Society, Vol. 8. No. I, 82-101, London.

V. Hanuš, M. Krs 1963 c: Palaeomagnctic Dating of Hydrothermal Mineralization on the Example of Spišsko-gemerské Rudohorie Area-Czechoslovakia. Rozpravy of the Czechoslovak Academy of Sciences, Vol. 73, 1-87, Praha.

M. Krs 1963: Reverse and Normal Remanent Magnetization in Hydrothermal Veins. Nature, Vol. 199, No. 4891, 365-366, London.

M. Krs 1964 : Geochronological Aspects of Polar Wandering Derived from Czechoslovak Hydrothermal Deposits. Pure and Applied Geophysics, Vol. 57, 1964/I, 96-102, Milano. 